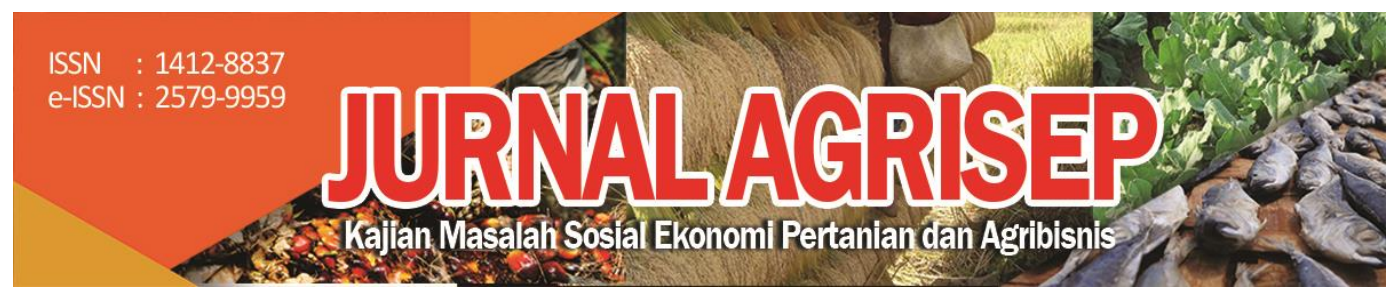

DOI: 10.31186/jagrisep.20.1.157-178

\title{
KOMERSIALISASI LAHAN PERTANIAN DI KOYA BARAT DAN KOYA TIMUR, KOTA JAYAPURA
}

\section{Commercialization of Agricultural Land In West Koya And East Koya, Jayapura City}

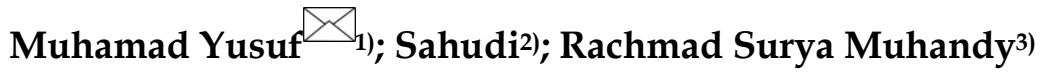 \\ 1),2),3)IAIN Fattahul Muluk Papua, Indonesia \\ Email: joesoef1974@gmail.com ${ }^{1)}$
}

\begin{abstract}
This paper aims to find out about the commercialization of agricultural land, and the current model of agricultural land commercialization in West Koya and East Koya, and the Jayapura City's goverment attitude toward the lack of agricultural land in Jayapura City area. This is a qualitative research, using a social phenomenology paradigm. The results showed that the increasingly dense population of Jayapura City has led in the expansion of the city towards Koya region which is suburb area. Smooth transportation facilities and good infrastructure make Koya region more evolving. The land price in Koya area depends on the sale value of tax object, it is also influenced by the lack of land used as a place to live due to the density increasing of urban area so that the resident seek residential land in Koya area. Transmigrants or farmers who have no knowledge basis in agriculture, and have difficulty dealing with rice pests, causing them to be reluctant to plant rice, and difficult to adapt to the environmental situation. Farmers are more benefited by converting the farmland to fishery land. By utilizing former farmland to be used as a public fishing pond as amusement or tourism place. The economic pressure of community at the beginning of transmigration program was a heavy burden that felt by them, while the needs as supporting tools were hard to find. The high cost of living is the cause of transmigrants' inability to survive, therefore, they decided to leave their transmigration land by selling it to a second party.
\end{abstract}

Keywords: Transmigration, Commercialization, Agricultural land 


\begin{abstract}
ABSTRAK
Artikel ini bertujuan untuk mengetahui tentang terjadinya komersialisasi lahan pertanian, dan model komersialisasi lahan pertanian di wilayah Koya Barat dan Koya Timur Kota Jayapura pada saat ini, dan sikap pemerintah Kota Jayapura terhadap kurangnya lahan pertanian di wilayah Kota Jayapura. Merupakan penelitian kualitatif, dengan menggunakan paradigma fenomenologi sosial. Hasil penelitian menunjukkan semakin padatnya penduduk Kota Jayapura mengakibatkan perluasan kota mengarah ke wilayah Koya yang merupakan wilayah pinggiran. Sarana transportasi yang lancar dan infrastruktur yang baik, menjadikan wilayah Koya dapat berkembang. Harga tanah di wilayah Koya tergantung pada nilai jual objek pajaknya, dipengaruhi pula dengan minimnya lahan yang digunakan sebagai tempat tinggal akibat semakin padatnya wilayah perkotaan sehingga masyarakat kota mencari lahan hunian di wilayah Koya. Transmigran yang tidak memiliki dasar sebagai petani, dan sulitnya menghadapi hama padi, menyebabkan mereka enggan menanam padi, serta sulit beradaptasi dengan situasi lingkungan yang ada. Petani lebih diuntungkan dengan melakukan alih fungsi lahan menjadi lahan perikanan. Dengan memanfaatkan bekas lahan pertanian untuk dijadikan kolam pemancingan umum sebagai wahana hiburan. Tekanan ekonomi masyarakat pada awal transmigrasi digulirkan sangat berat dirasakan, kebutuhan lainnya sebagai alat motivasi sulit didapat. Biaya hidup yang tinggi menjadi penyebab ketidakmampuan transmigran untuk bertahan, sehingga memilih meninggalkan lahan transmigrasinya dengan menjualnya pada pihak kedua.
\end{abstract}

Kata Kunci: Transmigrasi, Komersialisasi, Lahan Pertanian

\title{
PENDAHULUAN
}

Papua yang pada tahun 1980an, gencar-gencarnya menjadi wilayah yang dijadikan obyek transmigrasi dari wilayah-wilayah yang padat penduduknya, misalnya penduduk dari wilayah pulau Jawa, dimana program ini dilaksanakan pada era Orde Baru dalam rangka pemerataan penduduk di seluruh wilayah Indonesia. Papua merupakan wilayah yang berada di ujung timur Indonesia, pada masa Orde Baru masih menyatu dengan Papua Barat, dengan luas \pm 3 kali luas pulau Jawa, dengan kepadatan penduduk yang masih sangat kurang menjadikan wilayah ini prioritas program transmigrasi, di samping wilayah lainnya seperti Kalimantan dan Sumatera.

Salah satu wilayah yang masuk dalam program transmigrasi di wilayah Propinsi Papua adalah wilayah Koya, yang masuk dalam wilayah administratif Kota Jayapura, wilayah tersebut telah dijadikan daerah transmigrasi pada era tahun 1980an, dimana asal para transmigran kebanyakan berasal dari pulau Jawa dan Sulawesi Selatan. Transmigran tersebut diberikan tanah cuma-cuma oleh Pemerintah sebanyak $2 \mathrm{Ha}$, dimana tanah 1/4 Ha digunakan untuk tempat tinggal, dan 13/4 Ha digunakan sebagai lahan pertanian atau bercocok tanam. 
Seiring dengan berkembangnya waktu, banyak dari para transmigran yang tidak mampu untuk mengelola lahan pertanian, dan pada akhirnya menjual lahan-lahan tersebut ke orang/pihak ketiga, untuk kembali pulang ke kampung halamannya, yang notabene para pembeli tersebut bukanlah transmigran. Kemudian setelah sekian tahun lamanya, tanah tersebut dijual kembali ke para pengembang perumahan atau investor lainnya seperti pengembang wisata pemancingan, yang dijual dengan harga fantastis. Wilayah tersebut bukan lagi digunakan sebagai lahan pertanian untuk menghasilkan pelbagai kebutuhan sayur-mayur bagi masyarakat Kota Jayapura, tetapi mulai menjadi perkotaan akibat dari pengembangan Kota Jayapura.

Permasalahan yang muncul kini ialah harga tanah di wilayah tersebut dalam jangka waktu 30 tahunan ini, dimana awalnya tanah-tanah tersebut diperoleh tanpa proses pembayaran ke pemerintah, akan tetapi sekarang dijual dengan harga yang melambung tinggi. Wilayah Koya yang kini terbagi atas wilayah Koya Barat dan Koya Timur yang dulunya berada dipinggiran kota, saat ini merupakan wilayah yang diperebutkan banyak pihak, ditambah lagi dengan adanya pembangunan jembatan penyeberangan yang menghubungkan Kota Jayapura menuju Holtekamp, sehingga mempercepat akses menuju wilayah Koya, membuat daerah ini banyak diincar oleh para investor pengembang, sehingga sudah jarang dijumpai lagi tanaman-tanaman padi ataupun sayurmayur di daerah tersebut, namun berganti pemandangan dari bangunanbangunan pertokoan dan perkantoran di wilayah tersebut.

Penelitian ini dilakukan untuk mengetahui tentang terjadinya komersialisasi lahan pertanian, dan model komersialisasi lahan pertanian pada lahan-lahan pertanian di wilayah Koya Barat dan Koya Timur, Kota Jayapura, serta sikap pemerintah Kota Jayapura terhadap kurangnya lahan pertanian di wilayah Kota Jayapura.

Kajian literatur dalam penelitian ini adalah sebagai berikut: Hossaimah dan Slamet Subari (2017), mengatakan: pada Kecamatan Galis Kabupaten Pamekasan, menunjukkan bahwa kurun waktu antara 2009-2015 mengalami alih fungsi lahan menjadi perumahan, pelayanan umum, dan tempat usaha (warung, ruko) seluas 1,46 Ha di tahun 2011. Adapun yang menjadi faktor yang berhubungan dengan alih fungsi lahan adalah produktivitas lahan, kegunaan lahan, permulaan lahan, berubahnya perilaku, hubungan lahan dengan pemiliknya, serta perizinan.

Celsius Talumingan Sherly G. Jocom (2017), mengatakan: nilai rata-rata seluruh daya dukung lahan pertanian tanaman pangan di Kabupaten Minahasa Selatan sebesar 0,414. Dapat diartikan bahwa lahan pertanian pada Kabupaten Minahasa Selatan belum mampu melaksanakan serta memberikan kecukupan pangan.

Susvia Delta Kusdiane, dkk (2018), mengatakan: alih fungsi lahan pertanian berpengaruh terhadap meluruhnya lahan peranan pertanian pada 
kehidupan sosial ekonomi warga. Lunturnya makna lahan pertanian menjadi pendorong kesulitan mewujudkan regenerasi petani di Kecamatan Cimanuk.

Linda Cristi Corolina, dkk (2014), mengatakan: alih fungsi lahan pertanian untuk pembangunan kawasan perumahan diatur dalam penetapan pola ruang untuk kawasan perumahan sedangkan prosentase lahan pertanian yang dialihkan untuk lahan perumahan sebesar $60 \%$ dengan penyebaran yang tidk merata di seluruh Kabupaten Siduarjo.

Yunastiti Purwaningsih, dkk (2015), mengatakan: sumber pendapatan rumah tangga di Kecamatan Colomadu Karang Anyar Jawa Tengah memperlihatkan sebagian besar rumah tangga tidak alih fungsi dan alih fungsi lahan memiliki pendapatan utama dari usaha tani dan wiraswasta. Rata-rata pendapatan perbulan dari usaha tani untuk rumah tangga tidak alih fungsi lahan lebih besar dibandingkan rumah tangga alih fungsi.

Mursid Zuhri (2018), mengatakan: alih fungsi lahan pertanian ke nonpertanian terpengaruh akibat perkembangan perkotaan yang pesat. Pola ruang dan tempat alih fungsi lahan sawah dipengaruhi faktor pertumbuhan penduduk perkotaan, pergeseran struktur ekonomi, pengembangan rumah tangga pertanian pengguna lahan serta berubahnya luas penguasaan lahan. Kebijakan pengendalian alih fungsi lahan pertanian merupakan konsistensi penerapan RTRW Provinsi serta kabupaten.

Perbedaan yang utama pada penelitian yang dilakukan oleh peneliti terletak pada lokasi yang berbeda, terjadi perluasan perkotaan sehingga melambungnya harga tanah, yang berdampak pada semakin berkurangnya lahan-lahan pertanian, dan masalah pemberian lahan pertanian dari pemerintah kepada para transmigran, yang mempermudah transmigran untuk menjual lahan pertaniannya, dan ketidakmampuan petani untuk mengelola lahan serta adanya penguasaan tanah oleh investor dan spekulan tanah.

Landasan teori yang menjadi rujukan pada penelitian ini adalah sebagai berikut. Hierarkhi Kebutuhan Maslow dalam Malayu S. P. Hasibuan (2001: 83): 1. Manusia merupakan makhluk hidup yang memiliki keinginan. Ia selalu berhasrat lebih banyak. Hasrat tersebut terus-menerus dan akan berhenti ketika akhir hayat tiba.

2. Suatu kebutuhan yang telah terpenuhi tidak menjadi motivasi baginya, hanya kebutuhan yang belum terpenuhi sebagai pendorong motivasi.

3. Kebutuhan individu tersusun dalam suatu tingkatan/hierarkhi, yang diawali pada tingkatan kebutuhan yang terendah physiological, safety, and security, affiliation oracceptance, esteem or status, dan terakhir self actualization.

Parson dalam George Ritzer dan Douglas J. Goodman (2011: 121), mengatakan bahwa suatu fungsi merupakan kumpulan kegiatan yang difokuskan pada pemenuhan kebutuhan tertentu atau kebutuhan sistem. Lebih lanjut dikatakan bahwa: Ada empat fungsi penting diperlukan semua sistem: adaptation (A), goal attainment (G), integration (I), serta latensi (L) atau 
pemeliharaan pola. Secara bersama-sama keempat imperative fungsional ini dikenal sebagai skema AGIL. Agar tetap bertahan (survive), suatu sistem harus memiliki empat fungsi ini:

1. Adaptation (adaptasi): sebuah sistem harus menanggulangi situasi eksternal yang gawat. Sistem harus menyesuaikan diri dengan lingkungan dan menyesuaikan lingkungan itu dengan kebutuhannya.

2. Goal attainment (pencapaian tujuan): sebuah sistem hendaknya mendefinisikan dan mencapai tujuan utamanya.

3. Integration (integrasi): sebuah sistem harus mengatur antar hubungan bagian-bagian yang menjadi komponennya. Sistem juga harus mengelola antar hubungan ketiga fungsi penting lainnya (A, G, L).

4. Latency (pemeliharaan pola): sebuah sistem hendaknya memperlengkapi, memelihara, serta memperbaiki baik motivasi individual maupun pola kultur yang menciptakan serta mendukung motivasi.

H. Emerson dalam Soewarno Handayaningrat (1995: 16), mengatakan efektifitas merupakan pengukuran dalam artian tercapainya sasaran atau tujuan yang telah ditetapkan sebelumnya. Lebih lanjut dijelaskan oleh Soewarno Handayaningrat yang bersandar pada pemikiran Emerson tersebut, menjelaskan: Efektifitas sesuatu yang memiliki arti pencapaian sasaran dan tujuan sesuai dengan rencana yang telah ditetapkan. Sebaliknya bila suatu sasaran dan tujuan tidak tercapai sesuai rencana yang telah ditetapkan, maka tidak efektif.

Pandangan Parson dalam Bryan S. Turner (2012: 28) tentang modernitas sebagai suatu teori tentang modernitas, yang esensinya adalah satu pandangan tentang perkembangan progresif mengenai struktur-struktur yang ada pada suatu masyarakat dan terintegrasi secara fungsional. Comte dalam Turner (2012: 10): Modernitas terutama ialah sebuah produk dari perkembangan kekuatan pengetahuan. Durkheim dalam Turner (2012: 14), bekerja dengan sebuah tipologi dikotomis tentang masyarakat-masyarakat, yaitu masyarakat tradisional dan masyarakat modern. Dalam tahap transisi dari masyarakat tradisional ke masyarakat modern, bentuk-bentuk dari integrasi yang bersifat mekanis (yang ditandai dengan karakteristik dari kesadaran kolektif dengan fokus pertahanan yang kuat pada kelompok dan hubungan secara langsung atau hubungan yang bersifat mekanis antara sistem-sistem nilai, dan para pelaku sosial), diganti oleh bentuk-bentuk solidaritas yang bersifat organik (yang ditandai dengan individualisme dan kooperasi, serta ditujukan dalam normanorma yang bersifat umum, sebagaimana lawan dari nilai-nilai yang bersifat subtantif).

Amanda (2016), mengatakan ketersediaan lahan pertanian yang semakin berkurang menimbulkan aspek-aspek sosial pada masyarakat turut mengalami perubahan seperti juga modal sosial. Hal tersebut amat disayangkan karena komponen modal sosial pada masyarakat seperti jaringan, norma, serta 
kepercayaan merupakan bagian dari kehidupan sosial yang mendorong tindakan kolektif secara lebih efektif untuk pencapaian tujuan secara bersama.

Hahn-Been Lee yang dikutip Sondang P. Siagian (1990: 3): Pembangunan dapat diartikan sebagai suatu usaha atau rangkaian usaha pertumbuhan, dan perubahan yang terencana yang dilakukan secara sadar oleh suatu bangsa, negara, dan pemerintah, menuju modernitas dalam rangka pembinaan bangsa (nation-building). Bintoro Tjokroamidjodjo (1996: 49): Tujuan dari perencanaan pembangunan disebut juga tujuan-tujuan pembangunan (development objektives). Adanya usaha pencapaian tujuan-tujuan pembangunan tertentu ini merupakan ciri-ciri dari suatu perencanaan pembangunan.

Parson dalam Chris Jenks (2013: 85): Tindakan sosial merupakan semua perilaku manusia yang dimotivasi dan dituntun oleh makna-makna yang mengerti aktor di dunia luar, makna-makna yang dianggapnya penting serta yang diresponnya. Jadi elemen penting pada tindakan sosial merupakan sensitifitas aktor terhadap makna orang-orang serta hal-hal di sekitarnya, pandangan terhadap makna-makna itu, serta reaksi-reaksinya terhadap pesanpesan yang dibawa oleh makna-makna itu. Garfinkel dalam Turner (2012: 122), menegaskan: Agar norma-norma, nilai-nilai, dan lembaga-lembaga sosial selalu ada, aktor-aktor perlu memiliki suatu keterampilan dan pemahaman yang kompleks tentang tindakan-tindakan mereka sendiri, suatu pemahaman dan kesadaran tentang apa yang mereka lakukan. Erving Goffman dalam Turner (2012: 125): Kesadaran refleksi para aktor, juga kemampuan terampil mereka untuk melakukan penyesuaian dan adaptasi dalam rangkaian membuka suatu interaksi sebagai tanggapan atas tanda-tanda peringatan dan petunjukpetunjuk. James Coleman dalam Turner (2012: 293): Suatu tindakan bisa dianggap atau dijelaskan jika dan hanya jika tindakan itu diperlukan sebagai (tindakan yang) rasional.

\section{METODE PENELITIAN}

Penelitian ini menggunakan metode deskriptif kualitatif, dengan menggunakan paradigma fenomenologis sosial. Penelitian memusatkan perhatian pada makna dan pengalaman subjektif sehari-hari, bertujuan menerangkan bagaimana objek dan pengalaman tercipta secara penuh makna dan dikomunikasikan dalam kehidupan sehari-hari. Menggunakan model studi kasus yang intrinsik atau satu kasus yang berkaitan dengan penjualan lahan pertanian untuk dialihfungsikan menjadi kolam pemancingan, perumahan, dan pertokoan. Setting penelitian dilakukan di Koya Barat dan Koya Timur Kota Jayapura, yang dahulunya merupakan wilayah transmigrasi. Instrumen kunci dalam penelitian adalah tokoh masyarakat Koya Barat dan Koya Timur, serta peneliti sendiri. Melakukan pencaharian data tertulis dengan memperoleh data tersebut melalui teknik studi kepustakaan. Penelitian ini berlangsung di lokasi penelitian pada bulan April hingga November 2019. Melaksanakan observasi 
partisipatoris secara pasif, dilakukan pula in-depth interview. Menggunakan teknik analisis model alir yang dikembangkan Matthew B. Miles dan Michael A. Huberman (1992: 18): Menganalisis data dengan membagi ke dalam tiga bagian: (1) Reduksi data, yakni merangkum data, memilih hal-hal yang pokok, memfokuskan pada hal-hal yang penting, dan membuang hal-hal yang tidak diperlukan; (2) Display data, yakni menyajikan data, dengan membuat uraian singkat, bagan, hubungan antar kategori, dan sejenisnya; (3) Verifikasi, yakni penarikan kesimpulan.

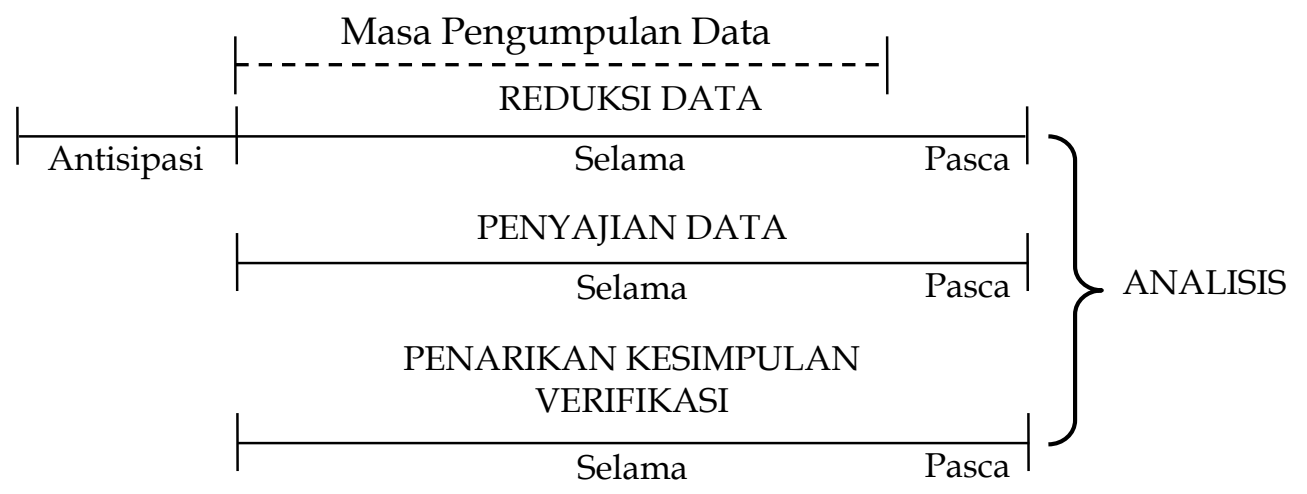

Gambar 1.

Komponen-Komponen Analisis Data Model Alir

\section{HASIL DAN PEMBAHASAN}

\section{Komersialisasi Lahan Pertanian dan Transmigran Meninggalkan Lokasi Pertanian di Wilayah Koya Barat dan Koya Timur Kota Jayapura}

\section{Komersialisasi Lahan Pertanian di Wilayah Koya Barat dan Koya Timur}

Pesatnya pembangunan perkotaan secara otomatis memberikan dampak pada wilayah pinggiran kota yang ikut berubah mengikuti gerak pusat kota. Wilayah Koya yang berada di pinggiran Kota Jayapura, dahulunya merupakan wilayah transmigrasi, baik transmigran lokal maupun transmigran nasional yang berasal dari berbagai wilayah di Indonesia. Saat ini wilayah tersebut bukan lagi berwajah pedesaan, tetapi lebih mirip kota kecil yang berada di pinggiran kota induknya yaitu Jayapura, pembangunan sarana dan prasarana semakin meningkat, baik yang dilakukan pemerintah, maupun para investor swasta dan masyarakat umum lainnya, yang berebut lahan untuk dijadikan perumahan atau obyek wisata dan pertokoan, yang membuat wilayah ini makin lama semakin padat penduduknya. Mahalnya bahan material bangunan dan lahan, menyebabkan sebagian masyarakat lebih memilih membeli perumahan bersubsidi yang marak diperjualbelikan oleh para investor perumahan, sehingga masyarakat dapat langsung menikmati huniannya. Ada pula masyarakat yang 
membeli lahan kaplingan yang awalnya merupakan lahan pertanian, kemudian dibeli oleh investor dan selanjutnya dipecah menjadi kaplingan-kaplingan berukuran kecil, untuk dijadikan rumah tinggal bagi masyarakat yang membutuhkan. Maraknya pembangunan perumahan di Koya Barat dan Koya Timur merupakan salah satu kebutuhan mendesak yang dilakukan akibat ledakan penduduk yang berada di pusat Kota Jayapura, kebutuhan perumahan baik secara pribadi, karyawan swasta maupun kebutuhan perumahan bagi PNS sudah merambah ke wilayah tersebut, dimana wilayah jantung Kota Jayapura dan kota Distrik sekitarnya sudah tidak mampu melakukan pengembangan perumahan akibat lahan yang terbatas. Semakin padatnya penduduk Kota Jayapura, maka perluasan Kota Jayapura mengarah wilayah Koya yang merupakan pinggiran Kota Jayapura yang cukup luas. Menurut data BPS Kota Jayapura (2019), wilayah tersebut mencapai 9.247.107Ha untuk Koya Timur dan 3.885.019Ha untuk Koya Barat, sedangkan yang diberikan kepada transmigran secara keseluruhan seluas $5.200 \mathrm{Ha}$, untuk tempat tinggal dan bertanam padi agar Kota Jayapura mampu berswasembada padi. Namun tanaman tersebut sudah tinggal sebagian kecil saja, $\pm 150 \mathrm{Ha}$, dimana selebihnya telah berubah menjadi kolam pemancingan, perkebunan, pertokoan, perumahan serta kantorkantor baik pemerintah maupun swasta dan juga dibangun berbagai fasilitas umum lainnya yang digunakan untuk kepentingan masyarakat.

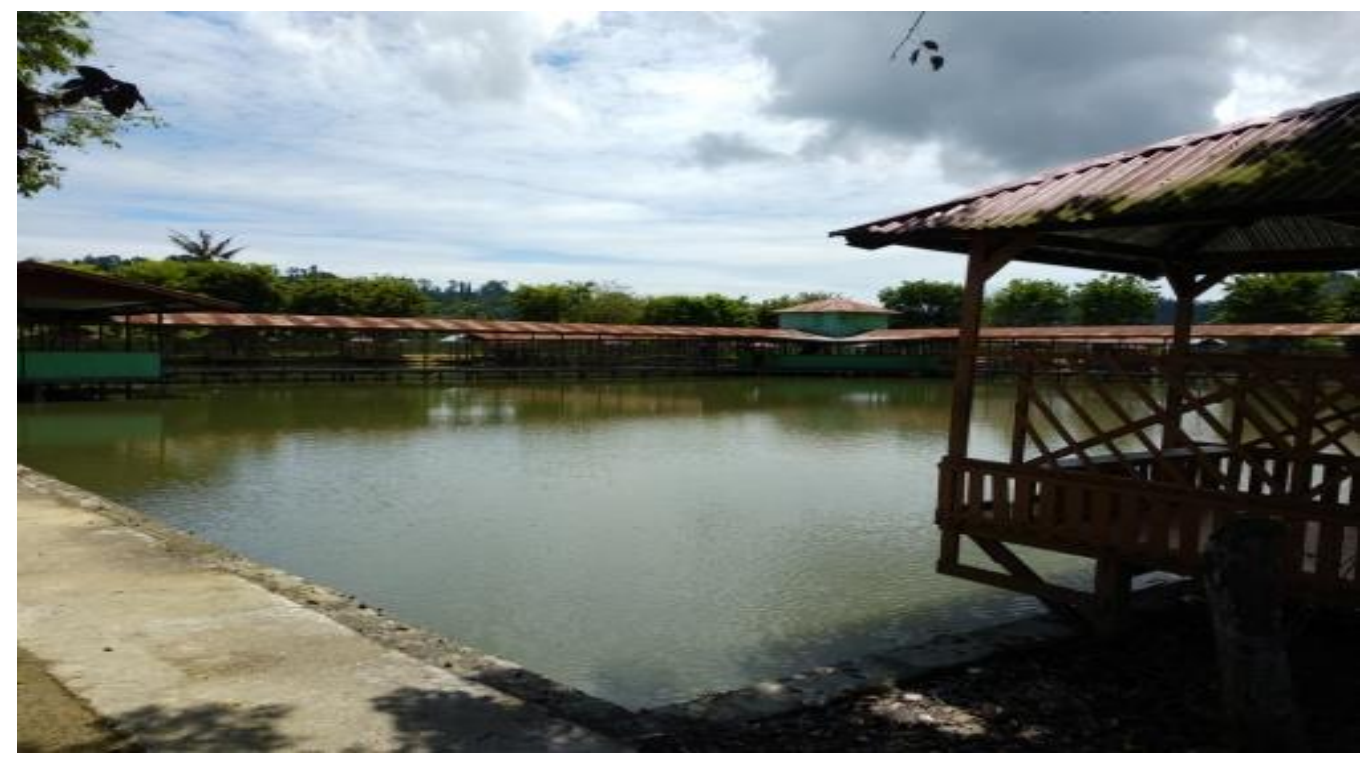

Gambar 2.

Kolam Pemancingan Yudistia Koya Barat 


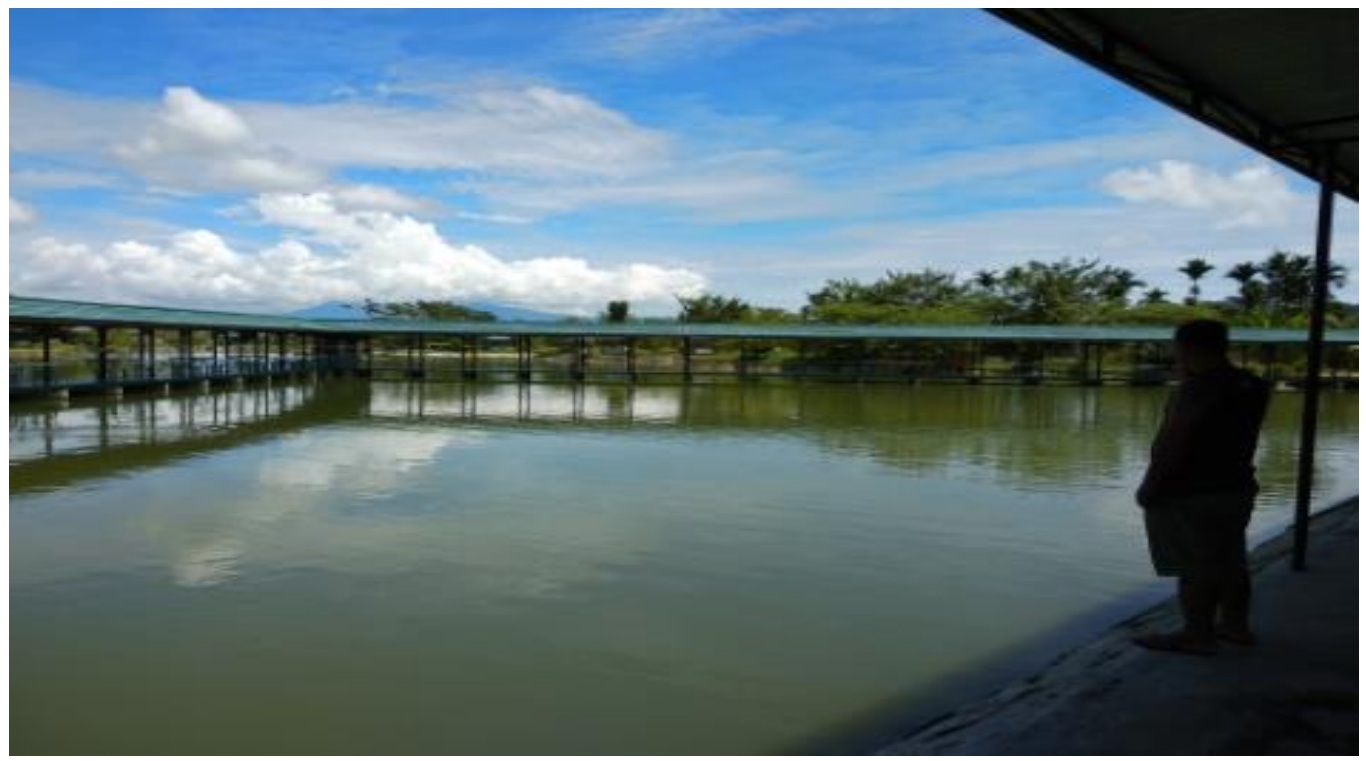

\section{Gambar 3}

\section{Kolam Pemancingan Aji Kencana Koya Timur}

Perkembangan transportasi di Kota Jayapura yang sudah menjangkau daerah-daerah pinggiran, membuat semakin mudahnya akses menuju Koya Barat dan Koya Timur untuk menuju pusat Kota Jayapura, maka semakin pesat pula pembangunan di wilayah tersebut, terlebih lagi dengan adanya pembangunan jembatan yang menghubungkan wilayah Hamadi dengan Holtekamp. Arus transportasi yang lancar merupakan faktor pendukung utama terjadinya perubahan pesatnya pembangunan. Wilayah Koya dilalui oleh angkutan pedesaan yang melintasinya dari Abepura menuju Skouw Sae. Ada pula angkutan pedesaan yang hanya melayani jalur Koya Barat dan Koya Timur saja. Dibukanya jembatan penyeberangan dari Hamadi ke Holtekamp yang masih berada di wilayah Koya Barat, sehingga memudahkan orang yang tinggal di Koya untuk menuju jantung Kota Jayapura, yang tidak harus melalui Kota Distrik Abepura dan Distrik Jayapura Selatan untuk dapat menuju pusat Kota Jayapura dalam waktu yang singkat. Transportasi yang lancar dan infrastruktur yang semakin baik membuat keuntungan besar bagi wilayah tersebut untuk dapat berkembang lebih maju. Dengan akses yang semakin mudah menuju Koya Barat dan Koya Timur, menunjukkan semakin mudahnya perubahan kearah modernisasi, sehingga yang tadinya merupakan wilayah pedesaan berubah menjadi perkotaan, ditambah semakin banyaknya perumahan, pertokoan, dan sarana hiburan serta fasilitas umum lainnya yang dibangun pihak swasta dan pemerintah Kota Jayapura yang memiliki fungsinya masingmasing dalam memenuhi kebutuhan masyarakat yang merupakan ciri dari perkotaan. 


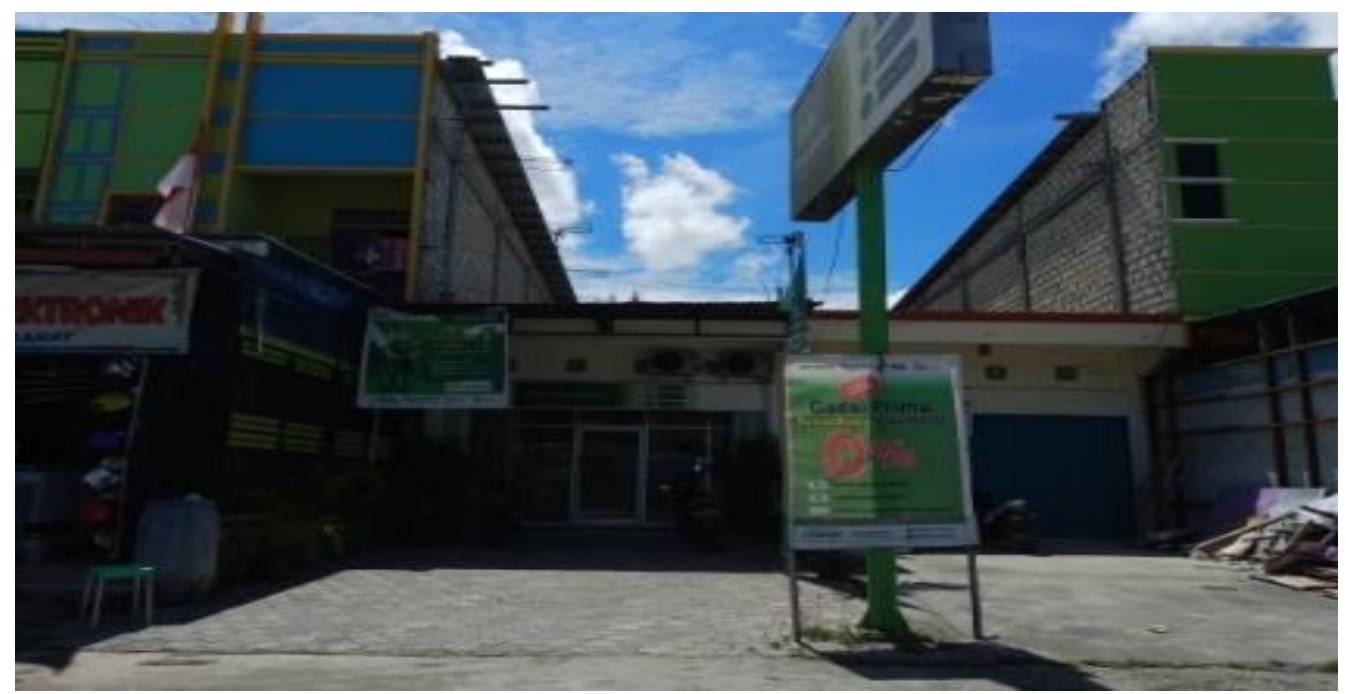

Gambar 4.

Gedung Perkantoran dan Pertokoan Di Sepanjang Jalan Poros

Kota Jayapura merupakan perkotaan yang lebih banyak daratan tinggi ketimbang daratan rendahnya dengan kontur tanah Kota Jayapura yang berbukit, dimana untuk melakukan pengembangan perkotaan sulit untuk dilakukan. Semakin pesatnya pertumbuhan penduduk di Kota Jayapura dimana semakin banyaknya kaum imigran menuju Kota Jayapura, maka semakin sempitnya ruang huni masyarakat Kota Jayapura, untuk itu masyarakat Kota Jayapura mulai melirik wilayah pinggiran Kota Jayapura yang sekiranya strategis kedepannya untuk mampu berkembang kearah wilayah perkotaan dan mampu memiliki nilai jual yang tinggi, dimana wilayah tersebut telah memiliki fasilitas yang diinginkan oleh masyarakat. Wilayah yang sekarang ini menjadi incaran masyarakat Kota Jayapura untuk dijadikan aset hunian adalah wilayah Koya Barat dan Koya Timur yang letaknya di pinggiran Kota Jayapura, wilayah ini lebih layak dijadikan perkotaan karena daerahnya yang datar dan cukup luas untuk pengembangan kota. Wilayah ini bukan hanya menjadi incaran warga sipil, tetapi juga menjadi incaran pemerintah kota untuk mengembangkan fasilitas pemerintah untuk kedepannya dijadikan wilayah perkotaan, yang dipersiapkan lahan untuk pembangunan gedung perkantoran dan hunian pegawai negeri sipil. Semakin sempitnya wilayah Kota Jayapura sehingga membutuhkan perencanaan pembangunan untuk memperluas wilayah kota kearah pinggiran Kota Jayapura ke wilayah yang lebih efektif. Wilayah Koya Barat dan Koya Timur merupakan wilayah yang strategis dalam pengembangan Kota Jayapura karena wilayah tersebut cukup luas dan datar untuk dijadikan wilayah perkotaan. 


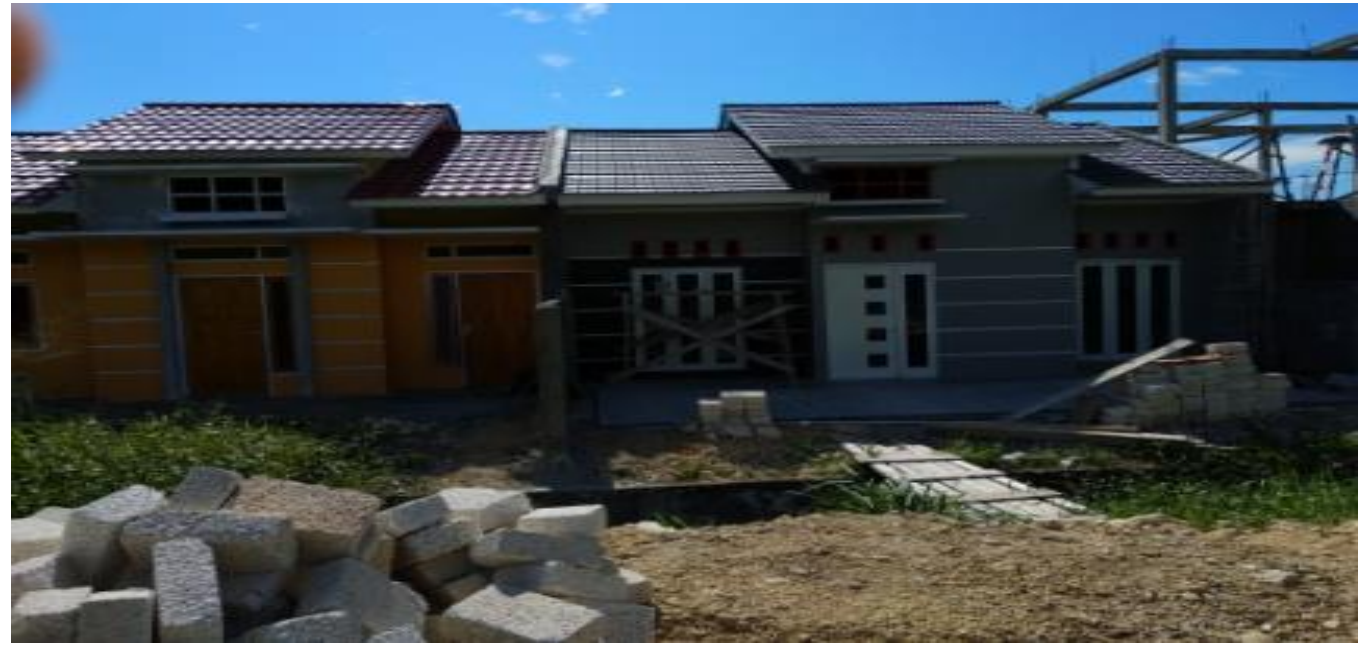

Gambar 5.

Pembangunan BTN Di Jl. Abepura Koya Barat

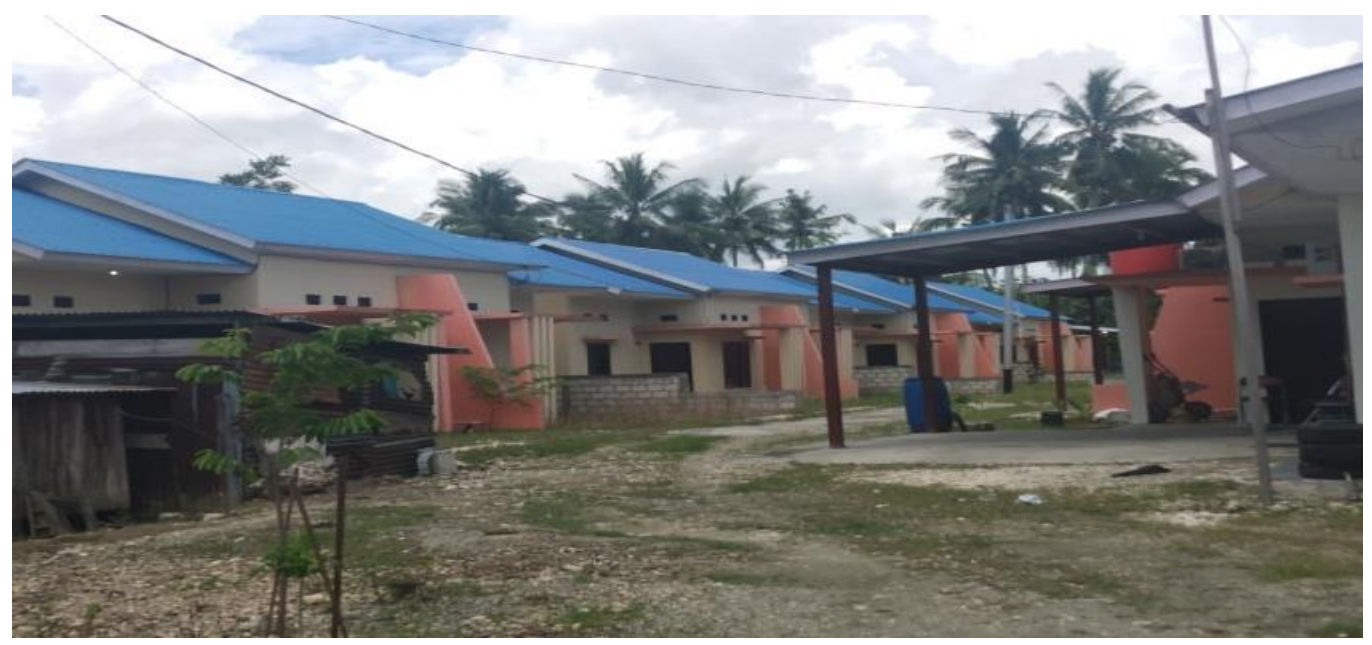

\section{Gambar 6}

\section{Kolam Pemancingan Aji Kencana Koya Timur}

Harga tanah sangat dipengaruhi oleh fasilitas penunjang di sekelilingnya yang salah satunya adalah sarana transportasi. Semakin dekat tanah tersebut dengan jalan utama akan semakin mahal harganya, atau dengan kata lain dapat dilihat dari harga jual objek pajak (NJOP) yang semakin lama semakin meningkat, terlebih bila tanah tersebut berada di wilayah yang strategis. Wilayah pusat Kota Jayapura sudah tidak terdapat lagi harga tanah Rp. 3.000.000/meter persegi, untuk mendapatkan harga dibawah harga tersebut dapat diperoleh di wilayah pinggiran Kota Jayapura, sehingga orang berbondong-bondong mencari lahan di wilayah Koya Barat dan Koya Timur, 
harga tanah di wilayah ini relatif cukup murah yaitu berkisar antara Rp. 300.000 sampai dengan Rp. 500.000/meter persegi, dilihat dari NJOP wilayahnya. Semakin dekat dengan jalan utama, maka makin mahal tanah tersebut, seperti halnya tanah yang terletak di pinggir jalan poros telah mengalami kenaikan yang signifikan yaitu mencapai Rp. 1.000.000,- per meter persegi bahkan ada pula yang lebih dari harga tersebut. Melambungnya harga tanah, menyebabkan banyak diantara transmigran menjual tanah pertanian dan kembali pulang ke kampung halaman, atau membeli perkarangan yang lebih kecil. Harga tanah yang melambung dipengaruhi pula dengan minimnya lahan yang dapat digunakan untuk tempat tinggal akibat semakin padatnya wilayah perkotaan sehingga masyarakat mencari lahan hunian terdekat dengan kota agar lebih efektif dalam melaksanakan pekerjaan. Nilai harga tanah di wilayah Koya Barat lebih tinggi dibanding dengan Koya Timur akibat lebih dekatnya wilayah Koya Barat dengan pusat Kota Jayapura.

Pertumbuhan penduduk yang pesat bukan hanya dari perkembangan penduduk asli yang ada di Kota Jayapura, melainkan juga diakibatkan karena migrasi penduduk dari kota dan kampung lainnya di sektiar Provinsi Papua, dan juga dari kota lain yang ada di Indonesia. Sehingga untuk mencari lahan kosong yang datar agar dijadikan pemukiman di tengah Kota Jayapura sangat sulit, dimana daerah perbukitan ketika ingin dijadikan lahan yang datar, harus mengeluarkan dana yang besar, karena pembangunan harus melalui tahapan yang panjang salah satunya pematangan tanah. Pertumbuhan penduduk yang tinggi mengakibatkan sulitnya orang mendapatkan lahan hunian di Kota Jayapura. Hal tersebut seperti yang diungkapkan Djoni dkk (2016) bahwa laju pertumbuhan penduduk merupakan salahsatu factor ekternal yang mempengaruhi alih fungsi lahan pertanian. Pendapat tersebut diperkuat pula oleh Suprianto dkk (2019), mengatakan bahwa faktor eksternal terdiri dari laju pertumbuhan penduduk serta kebijakan pembangunan Pemerintah Daerah.

Pertumbuhan penduduk yang mengikuti deret ukur, sedangkan lahan yang tersedia untuk menampung ledakan jumlah penduduk tidak bertambah sehingga penyebaran penduduk beralih ke wilayah pinggiran, termasuk wilayah Koya Barat dan Koya Timur serta wilayah Skouw Sae, dimana masyarakat memilih untuk lebih dekat dengan sumber pekerjaan yang dilakukan oleh masyarakat Kota Jayapura. Koya Barat dan Koya Timur, yang pada tahun 1980an daerah ini masih sangat sepi, padahal masuk dalam wilayah Kota Jayapura. Wilayah Koya Barat yang dibuka pada tahun 1984 dan Koya Timur pada tahun 1985, transmigran diberikan kemudahan mendapatkan tanah transmigrasi tanpa pembayaran. Tanah tersebut saat ini bukan lagi merupakan lahan pertanian, hanya sebagian kecil saja yang digunakan petani untuk dijadikan lahan pertanian. Terdapat perubahan dari keinginan awal pemerintah untuk swasembada pangan, dengan membebaskan lahan untuk dijadikan lahan pertanian. Kemudahan yang diberikan pemerinah untuk memberikan lahan 
pertanian kepada transmigran tanpa pembayaran dengan perolehan lahan seluas $2 \mathrm{Ha}$, dapat dijual oleh transmigran setelah 10 tahun pemakaian, pada tahun 1994 tanah di sekitar masih sangat terjangkau dibanding saat ini yang harganya melambung tinggi.

\section{Tabel 1. Jumlah Penduduk Kota Jayapura Mulai Tahun 2002 Hingga 2014}

\begin{tabular}{|c|c|c|}
\hline No. & Tahun & Jumlah Penduduk \\
\hline 1. & 2002 & 181,372 \\
\hline 2. & 2003 & 185,102 \\
\hline 3. & 2004 & 183,439 \\
\hline 4. & 2005 & 200,360 \\
\hline 5. & 2006 & 211,129 \\
\hline 6. & 2007 & 215,609 \\
\hline 7. & 2008 & 220,109 \\
\hline 8. & 2009 & 224,615 \\
\hline 9. & 2010 & 256,705 \\
\hline 10. & 2011 & 262.672 \\
\hline 11. & 2012 & 268.367 \\
\hline 12. & 2013 & 272,544 \\
\hline 13. & 2014 & 275,694 \\
\hline
\end{tabular}

Sumber Data: BPS Kota Jayapura Tahun 2019

Di Kota Jayapura pembelian tanah adat memiliki variasi, terkadang pemilik tanah berbeda dengan pemilik tanaman sagu atau tanaman lainnya, sehingga pembeli membayar kepada dua keluarga/sub suku yang berbeda. Pelepasan tanah adat bukan hanya dilakukan antar pribadi, juga dilakukan antara sub suku atau suku dengan pemerintah, seperti halnya tanah transmigrasi yang ada di Koya Barat dan Koya Timur, dimana pemerintah mendapatkan tanah tersebut dari suku Rolo dan suku Tamiauw untuk wilayah Koya Barat, dan suku Ramla untuk wilayah Koya Timur, yang kemudian dijadikan sebagai wilayah transmigrasi. Untuk memperoleh tanah, terdapat model yang dilakukan antara pemerintah dengan suku tersebut. Model pelepasan tanah adat kepada pemerintah untuk program transmigrasi melibatkan berbagai komponen, dimana struktur sosial yang dipandang merupakan sebuah jaringan yang terbentuk dari hubungan sosial serta mencakup kelompok sosial dimana setiap kelompok memiliki perannya sendiri, baik Kementerian Transmigrasi, BPN, dan pemilik tanah, dalam menyelesaikan permasalahan jual beli tanah untuk dijadikan lahan transmigrasi.

Kebutuhan akan hiburan di wilayah perkotaan tidak terdapat dipungkiri merupakan kebutuhan yang diperlukan untuk menghindarkan diri dari kejenuhan yang muncul dari hiruk-pikuknya wilayah perkotaan. Masyarakat perkotaan dipenuhi dengan pekerjaan yang rutin dilakukan sehingga 
membutuhkan waktu luang untuk menghilangkan kejenuhan. Bagi pegawai kantoran akan muncul hari yang dapat digunakan untuk berlibur, yakni hari Sabtu dan Minggu. Demikian halnya masyarakat Kota Jayapura yang minim dengan tempat hiburan. Membaca peluang tersebut, pengusaha dan sebagian warga Koya membuka kolam pemancingan, kolam tersebut dahulunya adalah lahan pertanian yang beralihfungsi menjadi kolam pemancingan, sehingga masyarakat transmigran yang memiliki modal merubah lahan pertanian menjadi kolam pemancingan, dan yang tidak memiliki modal, menjualnya kepada pemilik modal, pada akhirnya tanah tersebut berubah menjadi kolam pemancingan, pertokoan, perumahan, dan lain sebagainya. Kurangnya wahana hiburan di Kota Jayapura menyebabkan munculnya industri hiburan yaitu kolam pemancingan umum. Kolam pemancingan umum yang ada di Koya Barat dan Koya Timur bukan hanya dimiliki oleh masyarakat transmigran, tetapi juga dimiliki oleh investor yang tinggal di luar Koya Barat dan Koya Timur yang memiliki modal yang cukup untuk membeli dan mengelola lahan menjadi wahana hiburan. Diungkapkan oleh Nurmala K.D dan Iwan Rudiarto (2013) mengatakan : Lahan pertanian umumnya memiliki nilai jual yang rendah dibanding peruntukan non pertanian, hal tersebut menyebabkan lahan pertanian secara terus menerus akan mengalami konversi lahan ke non pertanian. Pendapat tersebut diperkuat pula oleh R. Janah dkk (2017) mengatakan : Alih fungsi lahan sangat signifikan mempengaruhi jumlah penduduk yang mempunyai luas kepemilikan lahan.

Persaingan antara pemilik modal yaitu investor dengan masyarakat transmigran yang kekurangan modal sangat nampak, dimana warga telah menerima perubahan, akan tetapi disisi lain masih banyak bentuk-bentuk kebiasaan lama yang sulit untuk dirubah sehingga kehidupan berlangsung diantara dua titik yang menimbulkan kebingungan pelakunya untuk mengembangkan usaha dibidang perikanan.

\section{Transmigrasi Meninggalkan Lokasi Pertanian}

Pada tahun 1980an wilayah Koya Barat dan Koya Timur masih sulit dijangkau, kendaraan angkutan pedesaan yang terbatas jumlahnya serta fasilitas penunjang masih sangat kurang, sehingga transmigran yang tidak mampu bertahan pada akhirnya kembali ke kampung halamannya dan menjual lahan pertaniannya, dimana lahan pertanian dapat dijual ketika telah mencapai 10 tahun menjadi petani. Harga kebutuhan pokok di Papua yang tinggi menyebabkan ketidakmampuan transmigran untuk bertahan. Pada awalnya lahan-lahan tersebut digunakan masyarakat untuk menanam padi, namun saat ini lahan-lahan tersebut sudah tidak dijumpai lagi petani yang menanam padi, hal ini disebabkan lahan-lahan tersebut tidak cocok untuk ditanami padi, dan untuk menanam padi dibutuhkan waktu yang cukup lama serta pengairan/irigasi yang baik, sedangkan irigasi di wilayah Koya Barat dan Koya 
Timur baru dapat terealisasi pada tahun 1992. Tekanan ekonomi masyarakat akan kebutuhan pada awal-awal transmigrasi digulirkan oleh pemerintah Orde Baru sangat berat dirasakan, dimana kebutuhan lainnya sebagai alat motivasi sulit didapat dalam artian wilayah tersebut belum tersedia apa yang diinginkan oleh masyarakat, sehingga memicu menurunnya tingkat kebutuhan terendah dan berakibat pada kebutuhan yang lebih tinggi.

Penempatan transmigran di suatu wilayah dibutuhkan pengamatan yang tepat terhadap tanah yang akan digunakan sebagai lahan pertanian. Ketika tidak dilakukan pengamatan atas tanah yang digunakan apakah cocok untuk lahan pertanian maka akan mengalami kegagalan bagi transmigran untuk melakukan cocok tanam di daerah tersebut. Ketidakmampuan petani dalam menghadapi hama padi menyebabkan petani enggan bertanam padi. Petani lebih diuntungkan dengan melakukan alih fungsi lahan menjadi kolam pemancingan, dimana hasilnya lebih menjanjikan dan tidak serumit menanam padi yang membutuhkan modal besar ketika terjadi serangan hama yang dapat berpengaruh pada rendahnya pendapatan, menyebabkan tabungan yang rendah, investasi rendah, kurangnya modal usaha, dan berakibat pada produktivitas lahan yang rendah, sehingga efektifitas lahan lebih tercapai dengan beralih pada pembudidayaan ikan air tawar, sehingga mampu mencapai kesejahteraan masyarakat Koya Barat dan Koya Timur. Sehingga dapat dikatakan bahwa efektifitas dari efektifitas pertanian di wilayah Koya Barat dan Koya Timur tidak tercapai.

Transmigran yang ada di Koya Barat dan Koya Timur Kota Jayapura, mereka berasal dari tempat asal ke tempat yang baru membutuhkan kemampuan beradaptasi bukan hanya dengan lingkungan alamnya tetapi juga dengan masyarakat asli untuk dapat menyesuaikan dirinya dengan lingkungan sekitar dan untuk dapat mempertahankan hidupnya. Transmigran yang tidak memiliki dasar sebagai petani akan mengalami kesulitan menyesuaikan diri dengan situasi lingkungan yang berubah, dalam artian bahwa mereka tidak mampu untuk berinteraksi dengan alam untuk memanfaatkannya, serta masyarakatnya untuk bekerjasama, disamping itu pola hidup yang berbeda dengan lingkungan awal transmigran berada sebelumnya di daerahnya hanya menemukan masyarakat yang memiliki kultur dan budaya yang sama sehingga menyulitkan transmigran untuk mampu beradaptasi dengan lingkungan di Papua yang memiliki kultur yang beragam.

Kota Jayapura yang merupakan kota yang berada di ujung timur Indonesia secara geografis sangat jauh dengan pusat ibukota Negara yaitu Jakarta. Dengan demikian secara otomatis maka berbagai barang kebutuhanpun semakin mahal, kebutuhan sangat bergantung pada beberapa daerah pemasok, seperti Jakarta, Surabaya, dan Makassar. Untuk itu biaya transportasi yang dibutuhkan semakin mahal, sehingga meningkatkan harga barang di pasaran, sehingga semakin tinggi biaya hidup yang harus ditanggung bagi warga Kota 
Jayapura. Biaya hidup yang tinggi di Kota Jayapura dapat menjadi penyebab ketidakmampuan masyarakat transmigran beradaptasi dengan lingkungannya sehingga meninggalkan lahan transmigrasinya dengan jalan menjualnya kepada pihak kedua, dan kembali ke kampung halamannya, atau dengan menjual tanahnya sebagian kepada orang lain demi melangsungkan hidupnya, sehingga dapat bertahan hidup atau digunakan sebagai modal usahanya. Hal ini yang menyebabkan sebagian wilayah Koya Barat dan Koya Timur saat ini dihuni oleh orang yang bukan transmigran asli. Kurangnya pemahaman yang kompleks dari transmigran sehingga tidak mampu mengembangkan lahan pertaniannya dan berdampak pada ketidakmampuan menutupi biaya hidup mereka.

\section{Model Komersialisasi Lahan Pertanian Di Wilayah Koya Barat Dan Koya Timur Kota Jayapura Dan Sikap Pemerintah Kota Jayapura Terhadap Kurangnya Lahan Pertanian}

\section{Model Komersialisasi Lahan Pertanian di Wilayah Koya Barat dan Koya Timur}

Penjualan bekas lahan pertanian di wilayah Kota Jayapura sangat memprihatinkan,ini akibat dari tuntutan pengembangan kota, sehingga yang dahulunya lahan-lahan di pinggiran Kota Jayapura yang merupakan wilayah transmigran kini berubah fungsi menjadi pemukiman penduduk kota dan arena hiburan memancing. Lahan pertanian disulap menjadi kolam-kolam pemancingan oleh investor yang datang dari kota dan menguasai lahan tersebut. Bukan hanya itu, lahan pertanian itu disulap pula menjadi pemukimanpemukiman berupa perumahan dengan berbagai ukuran yang dilakukan oleh pengembang perumahan sehingga beralih fungsi menjadi perumahan bersubsidi KPR, ada pula yang menjualnya dalam bentuk kaplingan-kaplingan untuk lahan tinggal dan ruko.

Untuk wilayah Koya Barat dan Koya Timur harga tanah kelas I yang bertepatan dengan jalan poros mulai melambung tinggi dibandingkan dengan tanah yang jaraknya jauh dari jalan poros, harga tanah tersebut berdasarkan nilai jual objek pajak (NJOP). Akan tetapi, tanah yang berada pada jalan poros umumnya telah dimiliki orang atau sekelompok orang atau instansi, bahkan badan usaha, sehingga sulit mendapatkannya dibandingkan dengan yang berada dibagian dalam yang merupakan bekas lahan pertanian. Harga kisaran penjualan bekas lahan pertanian yang ada di Koya Barat dan Koya Timur semakin lama semakin melambung, pembangunan kawasan perumahan sebagai alih fungsi yang akhirnya mendorong peningkatan permintaan lahan oleh investor sebagai pengembang perumahan atau spekulan tanah yang sengaja membeli tanah pertanian dan kemudian membelah menjadi kaplingan dan menjualnya kepada peminat tanah untuk perumahan sehingga harga lahan di sekitar Koya Barat dan Koya Timur semakin lama semakin meningkat dengan cepat. 
Penguasaan lahan pertanian hendaknya diberikan kepada para petani, akan tetapi lain halnya dengan lahan pertanian yang ada di wilayah Koya Barat dan Koya Timur, lahan tersebut telah banyak dimiliki oleh warga yang berasal dari luar Koya Barat dan Koya Timur. Pengembangan Kota Jayapura yang semakin lama semakin pesat membutuhkan lahan datar yang cukup luas untuk pengembangan kota kedepannya. Sebagai solusi yang diambil oleh masyarakat adalah daerah pinggiran Kota Jayapura yaitu wilayah Koya Barat dan Koya Timur, wilayah ini sangat strategis dalam hal pengembangan kota kedepannya, terlebih telah dibangunnya jembatan yang menghubungkan antara Kota Jayapura dengan Holtekamp, dimana letaknya berdekatan dengan Koya Barat. Penguasaan lahan bekas pertanian oleh para investor, dimana lahan pertanian dialihfungsikan menjadi perumahan, perkantoran, bahkan objek wisata. Lahanlahan pertanian di Koya Barat dan Koya Timur semakin lama semakin berkurang. Penduduk Kota Jayapura mulai bergeser menempati bekas lahan pertanian untuk dijadikan tempat tinggal dengan jalan membeli dari para transmigran atau dibeli dalam bentuk kaplingan melalui pihak pengembang. Hal ini disebabkan semakin pesatnya pertumbuhan penduduk dan semakin padatnya Kota Jayapura yang dipenuhi oleh berbagai bangunan perkantoran dan pemukiman, sehingga sensitifitas memunculkan reaksi masyarakat mencari lahan terdekat dengan pusat Kota Jayapura.

Peruntukan lahan pertanian semakin lama semakin berkurang, terlebih dengan berkembangnya wilayah perkotaan. Lahan pertanian telah beralih fungsi menjadi tempat-tempat hiburan dan perumahan, hal ini disebabkan karena akibat dari semakin padatnya penduduk. Demikian pula dengan yang terjadi di pinggiran Kota Jayapura yaitu di wilayah Koya Barat dan Koya Timur, yang dahulunya adalah lahan pertanian dari para transmigran yang diberikan oleh pemerintah untuk mengembangkan pertanian juga untuk pemerataan pembangunan dan pemerataan penduduk, pada saat itu Kota Jayapura khususnya masih sangat sedikit jumlah penduduknya, dan daerah pinggiran Kota Jayapura merupakan hutan belantara. Namun yang terjadi saat ini sudah jarang ditemui di wilayah Koya Barat dan Koya Timur petani yang menanam padi atau tanaman palawija lainnya. Tanah-tanah mereka telah beralih fungsi menjadi perumahan, dan tempat hiburan pemancingan. Pemanfaatan lahan pertanian di Koya saat ini lebih mengarah pada perubahan struktur ekonomi masyarakat, dimana masyarakat transmigran mencari peluang yang lebih baik lagi untuk dapat berkembang yaitu dengan jalan mengubah lahan pertanian menjadi kolam ikan. Disamping itu lahan pertanian di Koya semakin lama semakin menyempit akibat pertumbuhan penduduk Kota Jayapura yang semakin meningkat sehingga membutuhkan tempat tinggal, dimana pemerintah membangun rumah bersubsidi di wilayah Koya Barat. 


\section{Sikap Pemerintah Kota Jayapura Terhadap Kurangnya Lahan Pertanian}

Kota Jayapura yang semakin lama semakin berkurang lahan pertaniannya, maka dibutuhkan kepekaan pemerintah Kota Jayapura untuk mencari lahan pengganti atau memberikan inisiatif bagi warga untuk mengembangkan pertanian dengan menggunakan berbagai teknik pertanian yang lebih modern sehingga mampu mengembangkan pertanian secara lebih baik, sehingga tidak bergantung secara berlebihan pada daerah lainnya. Inisiatif ini hendaknya muncul untuk mengatasi kelangkaan hasil pertanian yang ada di pasar Kota Jayapura. Pemerintah Kota Jayapura belum memiliki lahan pengganti dimana luas Kota Jayapura yang tidak memungkinkan untuk membuka lahan pertanian, dengan kepadatan penduduk yagn cukup tinggi dibandingkan dengan wilayah lainnya di Papua, terlebih yang berkaitan dengan budi daya padi, akan tetapi dapat pula digunakan budi daya yang padat karya, kecil-kecilan dan aneka tanaman (multicrop).

Di era pemerintahan orde baru, pemerintah pusat mencanangkan program transmigrasi, memiliki fungsi diantaranya dalam rangka ketahanan pangan, pemerataan penduduk, dan alih pengetahuan tentang pertanian, serta meningkatkan kesejahteraan bagi orang-orang yang tidak memiliki lahan pertanian. Salah satu wilayah yang dicanangkan menjadi tempat pencanangan program transmigrasi adalah Provinsi Papua yang dulunya bernama Provinsi Irian Jaya, yang memiliki luas tiga kali pulau Jawa dengan penduduk yang masih sangat kurang dibandingkan dengan Provinsi lainnya di Indonesia. Salah satu wilayah Irian Jaya yang pada saat itu dijadikan tempat transmigran adalah wilayah Koya Barat pada tahun 1984 dan Koya Timur pada tahun 1985, pada saat itu wilayah ini dijadikan wilayah transmigran baik lokal yang berasal dari wilayah Irian Jaya maupun transmigran Nasional yang berasal dari wilayah Jawa dan Sulawesi Selatan. Di wilayah Irian Jaya yang saat ini menjadi dua provinsi yaitu Papua dan Papua Barat pada umumnya tanah dikuasai oleh pihak adat, sehingga untuk memperoleh lahan tersebut pemerintah daerah bekerjasama dengan pihak adat dalam pembebasan lahan untuk dijadikan lahan transmigrasi. Perolehan lahan untuk dijadikan lahan pertanian dari masyarakat adat dengan jalan yaitu Kementerian Transmigrasi melakukan pembelian kepada masyarakat adat dengan BPN sebagai perantara untuk melakukan mediasi antara pihak adat dengan Kementerian Transmigrasi, dengan mendatangkan suku-suku yang memiliki tanah di wilayah tersebut, misalnya Koya Barat berada pada suku Rollo yang ada di Skouw Sae, dan suku Tamiauw yang ada di Nafri (Keondoafian Nafri), sedangkan Koya Timur berada dalam wilayah suku Ramla.

Setiap kepala keluarga yang ikut dalam transmigrasi baik lokal maupun nasional memperoleh lahan dari pemerintah sebesar 1, 75 Ha untuk dijadikan lahan pertanian, dan 0,25 Ha untuk tempat tinggal. Lahan-lahan tersebut diperoleh oleh transmigran dengan catatan bahwa lahan tersebut tidak boleh 
diperjualbelikan selama jangka waktu 10 tahun. Dalam jangka waktu tersebut diharapkan para petani mampu mengembangkan usaha pertaniannya. Pemerintah memberikan kemudahan bagi transmigran dalam hal memperoleh lahan pertanian tanpa membayar, sehingga petani/calon petani tinggal mengolah lahan yang ada dengan bantuan bibit pertanian dari Kementerian Pertanian. Jika dibandingkan dengan saat ini lahan tersebut sudah mencapai 3 miliar harganya ketika membeli seluas $2 \mathrm{Ha}$, sehingga tanah bekas transmigrasi tersebut dapat dikatakan bahwa harganya melambung tinggi jika dibandingkan pada saat perolehan lahan yang tanpa biaya apapun yang diberikan pemerintah kepada transmigran. Wilayah Kota Jayapura yang semakin berkurang area pertaniannya, tidak menutup kemungkinan memasok hasil pertaniannya dari wilayah terdekat seperti Kabupaten Keerom, bahkan dari Kabupaten Wamena, dan Kabupaten Marauke, tidak menutup kemungkinan untuk memasoknya dari luar daerah Papua. Banyaknya kekurangan pasokan kebutuhan pertanian seperti beras, sehingga menimbulkan pola ketergantungan pangan, dimana sebelumnya wilayah ini merupakan penghasil padi., terlebih dengan bahan kebutuhan pokok lainnya. Hal tersebut sejalan dengan apa yang dikatakan Zullaika Tipe Nurhidayah (2017) mengatakan : Pertumbuhan penduduk namun lahan pertanian yang semakin menyempit maka dimasa mendatang kebutuhan pangan bisa tidak terpenuhi.

Semakin berkurangnya areal pertanian disuatu wilayah, maka hal ini merupakan sebuah tantangan untuk dapat memecahkan persoalan tersebut. Hal ini tidak dapat dengan serta merta dikesampingkan, karena berkaitan dengan kebutuhan orang banyak yaitu ketersediaan pangan dari hasil pertanian. Sikap pemerintah daerah dalam mengatasi kurangnya lahan pertanian untuk saat ini belum terpikirkan, karena belum dianggap sebagai suatu yang gawat, dimana lebih darurat adalah yang berkaitan dengan tempat tinggal penduduk Kota Jayapura, dengan semakin tingginya jumlah penduduk dan kepadatan Kota Jayapura, maka dibukalah perluasan kota kearah Koya Barat dan Koya Timur yang merupakan wilayah pinggiran Kota Jayapura, sehingga warga Kota Jayapura yang bekerja di Kota jayapura tetap bertempat tinggal di Kota Jayapura.

\section{SIMPULAN DAN SARAN}

\section{Simpulan}

Meningkatnya permintaan lahan oleh investor sebagai pengembang perumahan atau spekulan tanah yang membeli tanah pertanian dan menjualnya kepada warga Kota Jayapura untuk perumahan merupakan bentuk komersialisasi lahan. Harga tanah bergantung dari NJOP sebagai pedoman, dipengaruhi pula minimnya lahan tempat tinggal akibat padatnya wilayah kota. Pertumbuhan penduduk yang mengikuti deret ukur sedangkan lahan yang 
tidak bertambah sehingga penyebaran penduduk beralih ke pinggiran kota. Model pelepasan tanah adat kepada pemerintah untuk program transmigrasi melibatkan berbagai komponen, struktur sosial yang dipandang merupakan jaringan yang dibentuk dari hubungan sosial yang melingkupi kelompok sosial, setiap kelompok memiliki perannya, baik Kementerian Transmigrasi, BPN, dan pemilik tanah dalam menyelesaikan jual beli tanah. Kurangnya wahana hiburan penyebab munculnya industri hiburan, memanfaatkan bekas lahan pertanian menjadi kolam pemancingan umum, yang dimiliki transmigran juga investor. Persaingan antara investor dengan transmigran yang kekurangan modal sangat nampak, bentuk tradisi lama yang sukar ditinggalkan membuat kebingungan mengembangkan usaha perikanan. Ketidakmampuan petani menghadapi hama padi menyebabkan enggan menanam padi, dan beralihfungsi menjadi kolam ikan. Transmigran yang tidak memiliki dasar sebagai petani sulit beradaptasi dengan situasi lingkungan yang berubah, biaya hidup yang tinggi dan pola hidup yang berbeda dengan lingkungan daerah asal menyulitkan transmigran beradaptasi di lingkungan baru. Transmigran meninggalkan lahan pertanian dengan menjualnya baik sebagian atau seluruhnya. Pemanfaatan lahan pertanian saat ini mengarah pada perubahan struktur ekonomi masyarakat, transmigran mencari peluang yang lebih baik untuk berkembang dengan mengubah lahan pertanian menjadi kolam ikan. Pemerintah Kota Jayapura belum memiliki lahan pengganti untuk pertanian akibat luas Kota Jayapura yang tidak memungkinkan, dan belum dianggap sebagai suatu ancaman.

\section{Saran}

Kekurangan pasokan kebutuhan hasil pertanian, menimbulkan ketergantungan pangan bagi Kota Jayapura untuk itu dibutuhkan solusi kedepannya, yaitu hendaknya pemerintah Kota Jayapura membuat perencanaan yang matang tentang pengembangan Kota Jayapura ke wilayah Koya Barat dan Koya Timur sehingga tidak dikuasai investor dan spekulan tanah. Pemerintah diharapkan mampu memberikan modal usaha bagi transmigran untuk bersaing dalam mengelola lahan yang telah diberikan pemerintah agar tidak dijual kepihak lain serta tetap mempertahankan sisa tanah untuk melakukan cocok tanam. Adanya pelatihan tentang usaha yang mampu meningkatkan penghasilan transmigran seperti pengembangan perikanan air tawar. 


\section{DAFTAR PUSTAKA}

Amanda, A. 2016. Peran Agenci Budaya dan Praktik Multikulturalisme di Perkampungan Budaya Betawi (PBB) Setu Babakan. Jurnal Pemikiran Sosiologi, 3(2): 40-58.

Badan Pusat Statistik Kota Jayapura. 2019. Penduduk Kota Jayapura Dalam Angka BPS Kota Jayapura.

Corolina, Linda Cristi. Saleh, Choirul. dan Suwondo. 2014. Implementasi Kebijakan Alih Fungsi Lahan Pertanian Menjadi Kawasan Perumahan (Studi Pada Badan Perencanaan dan Pembangunan Daerah Kabupaten Sidoarjo). Jurnal Administrasi Publik (JAP), 2(2): 224-229.

Dewi, Nurmala Kumala. dan Rudiarto, Iwan. 2013. Identifikasi Alih Fungsi Lahan Pertanian Dan Kondisi Sosial Ekonomi Masyarakat Daerah Pinggiran Di Kecaatan Gunung Pati Kota Semarang. Jurnal Wilayah Dan Lingkungan, 1(2): 175-188.

Djoni, Suprianto, dan Cahrial, Eri. 2016. Kajian Alih Fungsi Lahan Pertanian Di

Kota Tasikmalaya. Jurnal Mimbar Agribisnis, 1(3): 233-244.

Handayaningrat, Soewarno. 1995. Pengantar Studi Ilmu Administrasi Dan Managemen. Jakarta. Gunung Agung.

Hasibuan, S.P. Malayu. 2001. Manajemen Sumber Daya Manusia, Edisi Revisi. Jakarta. Bumi Aksara.

Hossaimah dan Slamet, Subari. 2017. Percepatan Alih Fungsi (Konversi) Lahan Pertanian Ke Non Pertanian Di Kecamatan Galis Kabupaten Pamekasan. Jurnal Agrisaintifika, Jurnal Ilmu-ilmu Pertanian, 1(2): 97-108.

Janah, R. Eddy, B. T. dan Dalmiyatun, T. 2017. Alih Fungsi Lahan Pertanian dan Dampaknya Terhadap Kehidupan Penduduk Di Kecamatan Sayung Kabupaten Demak. Agrisocionomics: Jurnal Sosial Ekonomi Pertanian, 1(1): $1-10$.

Jenks, Chris. 2013. Culture, Studi Kebudayaan. Yogyakarta. Pustaka Pelajar.

Kusdiane, Susvia Delta. Soetarto, Endriatmo dan Sunito, Satyawan. 2018. Alih Fungsi Lahan dan Perubahan Masyarakat Di Kecaatan Cimanuk Kabupaten Pandeglang. Sodality: Jurnal Sosiologi Pedesaan, 6(3): 246-251.

Miles, B. Matthew dan Huberman A. Michael. 1992. Analisa Data Kualitatif. Jakarta. Universitas Indonesia. UI-PRESS.

Nurhidayah, Zullaika Tipe. 2017. Aspek Keadilan Alih Fungsi Lahan Pertanian Ke Non Pertanian (Studi Kecamatan Nguter Kabupaten Sukoharjo). Jurnal Repertorium, 4(2): 152-159.

Purwaningsih, Yunastiti. Sutomo, dan Istiqomah, Nurul. 2015. Analisis Dampak Alih Fungsi Lahan Terhadap Tingkat Ketahanan Pangan Rumah 
Tangga Petani Di Karanganyar, Jawa Tengah. Agraris: Journal of Agribusiness And Rural Development Research, 1(2): 98-107.

Ritzer, George dan Goodman J. Douglas. 2011. Teori Sosiologi Modern. Jakarta. Kencana Prenada Media Group.

Siagian, Sondang P. 1990. Administrasi Pembangunan. Jakarta. Haji Mas Agung. Suprianto. Cahrial, Eri. dan Nuryaman, Hendar. (2019). Faktor-faktor Pendorong Alih Fungsi Lahan Sawah Di Kota Tasikmaya. Jurnal Agristan, 1(1): 12-30.

Talumingan, Celsius. Jocom, G. Sherly. 2017. Kajian Daya Dukung Lahan Pertanian Dalam Menunjang Swasembada Pangan Di Kabupaten Minahasa Selatan. Agri-Sosio Ekonomi: Jurnal Ilmiah Sosial Ekonomi Pertanian, 13(1): 11-24.

Tjokroamidjojo, Bintoro. 1996. Perencanaan Pembangunan. Jakarta. Gunung Agung.

Turner, S. Bryan. 2012. Teori Sosial Dari Klasik Sampai Postmodern. Yogyakarta. Pustaka Pelajar.

Zuhri, Mursid 2018. Alih Fungsi Lahan Pertanian Di Pantura Jawa Tengah (Studi Kasus Kabupaten Brebes). Jurnal Litbang Provinsi Jawa Tengah, 16(1): 119130. 